\title{
PENGARUH MULTIMEDIA INTERAKTIF TERHADAP PEMBELAJARAN HURUF HIJAIYAH PADA SISWA TUNARUNGU RINGAN KELAS IX DI SLB-B DAN AUTIS TPA JEMBER
}

\author{
Anis Yulia Rachman, Rosika Novia M, Inna Hamida Z \\ PLB FIP IKIP PGRI Jember \\ email: anisyulia47@gmail.com
}

\begin{abstract}
Abstrak
Penelitian ini bertujuan untuk untuk mengetahui pengaruh multimedia interaktif terhadap pembelajaran huruf hijaiyah pada siswa tunarungu ringan kelas IX di SLB-B dan Autis TPA Jember. Penelitian ini menggunakan metode Single Subject Research (SSR) desain A-B. Subjek penelitian ini adalah siswa yang berinisial BG. Penelitian dilakukan dalam 10 sesi yang dilakukan pada dua fase yaitu fase baseline (A) adalah $60 \%, 66 \%, 66 \%, 70 \%$, dan $60 \%$. Sedangkan pada fase intervensi (B) antara lain $77 \%, 73 \%, 80 \%, 83 \%, 83 \%$. Dari data yang diperoleh kemudian dianalisis menggunakan analisis dalam kondisi dan analisis antar kondisi. Selisih perubahan level dari fase baseline (A) sampai awal fase intervensi (B) meningkat $(+17)$. Maka diketahui bahwa ada pengaruh multimedia interaktif terhadap pembelajaran huruf hijaiyah pada siswa tunarungu ringan kelas IX di SLB-B dan Autis TPA Jember.
\end{abstract}

Kata kunci: Tunarungu, multimedia interaktif, pembelajaran huruf hijaiyah

\section{PENDAHULUAN}

$\begin{array}{ccr}\text { Bagi } & \text { seorang muslim } \\ \text { membaca } & \text { Alquran merupakan }\end{array}$ kegiatan sehari-hari. Pada umumnya umat muslim mendapatkan ilmu untuk menghafal huruf Arab sejak usia balita hingga usia sekolah dasar. Sangat penting memperkenalkan kitab suci Alquran sejak dini karena itu adalah awal atau pondasi hidup.

Membaca Alquran diwajibkan bagi umat muslim karena Alquran adalah pedoman hidup untuk manusia agar selamat dunia dan akhirat. Sebagaimana termaktub dalam surat Al-Alaq ayat 1-5 yang artinya "bacalah dengan (menyebut) nama Tuhanmu yang menciptakan. Dia telah menciptakan manusia dari segumpal darah. Bacalah, dan Tuhanmulah yang maha pemurah, yang mengajar (manusia) dengan

http://doi.org/10.31537/speed.v3i2.282 perantaran qalam. Dia mengajarkan kepada manusia apa yang tidak diketahuinya".

Perintah membaca ini sedemikian pentingnya sehingga diulang dua kali dalam rangkaian wahyu pertama. Mungkin kita merasa heran ketika melihat bahwa perintah membaca ini ditujukan pertama kali kepada seseorang yang tidak pernah membaca suatu kitab apapun sebelum turunnya Alquran (QS 29:48).

Berdasarkan hal tersebut dalam membaca ayat-ayat Alquran terlebih dahulu kita harus paham dengan huruf-huruf Alquran atau bisa disebut dengan huruf hijaiyah. Huruf hijaiyah ialah kumpulan huruf-huruf arab yang berjumlah 29 huruf. Hurufhuruf inilah yang terpakai dalam Alquran dan dikenal pada masa sekarang (Abdurrahim, 2007, hlm. 
17). Dengan demikian, memahami huruf hijaiyah sangatlah penting. Karena dengan membaca Alquran merupakan jalan yang mengantarkan manusia mencapai derajat kemanusiaan. Tetapi pada kenyataannya siswa tunarungu ringan kelas 3 SMP untuk membaca huruf hijaiyah belum mencapai kompetensi yang diharapkan, hal ini menjadi dasar dalam mencari solusi bagaimana pembelajaran huruf hijaiyah dapat berhasil disampaikan pada siswa tunarungu.

Menurut Hallahan dkk (dalam Hernawati 2007, hlm. 2) siswa tunarungu adalah siswa yang mengalami ketidakmampuan mendengar, sehingga mengalami hambatan dalam memproses informasi bahasa melalui pendengarannya dengan atau tanpa menggunakan alat bantu dengar. Ketunarunguan berkaitan dengan kondisi pendengaran individu, yaitu terhambat dalam menangkap pembicaraan atau suara lainnya. Siswa tunarungu lebih mengutamakan indera penglihatan dalam proses pembelajaran.

Menurut Vygotsky (dalam Apriliani, 2013, hlm. 2) menyatakan bahwa "kemampuan berbahasa dan berpikir dapat saling mempengaruhi antara satu sama lainnya". Pendengaran merupakan alat sensori utama dalam berbicara dan berbahasa. Keterbatasan/hambatan dalam pendengaran yang dimiliki siswa berpengaruh juga pada perkembangan fungsi kognitifnya, karena siswa tunarungu mengalami kesulitan dalam memahami informasi yang bersifat verbal terutama konsep yang bersifat http://doi.org/10.31537/speed.v3i2.282 abstrak. Kemampuan berbahasa maka akan berdampak juga pada kemampuan berpikirnya. Dapat disimpulkan bahwa kemampuan siswa tunarungu berkaitan dengan kemampuan kognitifnya juga.

Berdasarkan hasil observasi yang dilakukan di SLB-B dan AUTIS TPA JEMBER, materi tentang huruf hijaiyah tidak diajarkan atau masuk dalam Standar Kompetensi dan Kompetensi Dasar dalam Kurikulum 2013. Seharusnya siswa tunarungu ringan kelas 3 SMP sudah mampu mengenal huruf-huruf hijaiyah (melafalkan dan isyarat). Hal ini menjadi bahan pemikiran pendidik dalam mencari solusi supaya pembelajaran tentang huruf hijaiyah dapat berhasil disampaikan kepada siswa tunarungu dan mencapai kompetensi yang diharapkan.

Dalam kegiatan belajar mengajar siswa tunarungu berbeda dengan kegiatan belajar mengajar siswa pada umumnya. Siswa tunarungu lebih tertarik pada hal-hal yang bersifat visual, dan penjelasan yang dilakukan secara berulang-ulang. Berdasarkan pemaparan diatas dapat diketahui bahwa permasalahan siswa tunarungu dalam pembelajaran huruf hijaiyah ialah keterbatasan dalam mempelajari huruf hijaiyah, dikarenakan huruf hijaiyah dianggap sebagai hal yang abstrak dan jarang digunakan dalam percakapan keseharian siswa tunarungu.

Media yang digunakan untuk mengenalkan huruf hijaiyah sangatlah banyak, diantaranya dengan buku iqra, kartu huruf hijaiyah, menulis di papan tulis dan komputer. Pembelajaran 
dengan menggunakan buku iqra dan menulis di papan sangatlah lazim digunakan serta monoton dalam pembelajarannya. Sehingga dibutuhkan media yang menarik dalam pembelajaran huruf hijaiyah, diperlukan media yang membantu mengoptimalkan indra visual siswa tunarungu. Menurut Mais (2016, hlm. 59) pembelajaran berbantu komputer bila dirancang dengan baik merupakan media pembelajaran yang efektif dapat memudahkan dan meningkatkan kualitas pembelajaran, meningkatkan motivasi belajar, materi dapat diulangulang sesuai keperluan tanpa menimbulkan rasa jenuh. Berdasarkan hal tersebut peneliti mencoba menerapkan multimedia interaktif berbasis Adobe Flash.

Multimedia interaktif berbasis Adobe Flash dapat membantu siswa tunarungu dalam menerima informasi dengan mengoptimalkan visualnya. Adobe Flash juga dapat memberikan stimulus siswa tunarungu untuk belajar, mengaktifkan respon, mendorong cara belajar interaktif, serta dapat mengatasi keterbatasan waktu sehingga siswa tunarungu dapat meneruskan pembelajaran di rumah.

Berdasarkan pemaparan di atas peneliti beranggapan bahwa multimedia interaktif berbasis Adobe Flash dapat membantu pemahaman siswa tunarungu pada pembelajaran huruf hijaiyah. Oleh sebab itu peneliti akan melakukan penelitian mengenai "Pengaruh Multimedia Interaktif Terhadap Pembelajaran Huruf Hijaiyah Pada Siswa Tunarungu Ringan Kelas IX di SLB-B dan Autis TPA Jember?".

http://doi.org/10.31537/speed.v3i2.282
METODE

Pada penelitian ini peulis menggunakan metode penelitian Singgle Subjeck Reasert (SSR). Menurut Sunanto (2005, hlm. 54) Single Subject Research (SSR) adalah suatu penelitian eksperimen yang dilaksanakan untuk mengetahui seberapa besar pengaruh dari perlakuan yang diberikan kepada subjek secara berulang-ulang dalam waktu tertentu. Desain yang digunakan dalam penelitian ini adalah desain A-B. Desain A-B merupakan desain dasar dari penelitian eksperimen subyek tunggal. Prosedur dsain ini disusun atas dasar apa yang disebut dengan logika baseline (baseline logic). Logika baseline menunjukan suatu pengulangan pengukuran perilaku atau target behavior pada sekurang- kurangnya dua kondisi yaitu kondisi baseline (A) dan kondisi intervensi (B) (Sunanto, 2005, hlm. 55). Sunanto, (2005, hlm. 56) menjelaskan bahwa pada desain A-B ini tidak ada replikasi (pengulangan) pengukuran dimana fase baseline (A) dan intervensi (B) masing-masing dilakukan hanya sekali untuk subyek yang sama.

Penelitian ini dilakukan pada bulan September sampai dengan Oktober 2018 di SLB-B dan AUTIS TPA Jember.

Subjek penelitian ini adalah siswa kelas IX dengan inisial BG. BG adalah siswa tunarungu ringan di SLB-B dan AUTIS TPA Jember. BG belum mengetahui huruf hijaiyah beserta isyaratnya. BG hanya dapat membaca beberapa huruf hijaiyah yaitu alif, ba, ta, tsa, jim, ha dan kha. 
Huruf hijaiyah jim, ha dan kha BG masih sulit membedakan karena bentuk huruf tersebut sama yang membedakan hanyalah letak titiknya. BG dalam berkomunikasi menggunakan verbal, isyarat dan tidak menggunakan Alat Bantu Dengar (ABD).

Instrumen yang digunakan dalam penelitian ini adalah tes praktik dan tes tulis. Pada tes praktik siswa mengisyaratkan huruf hijaiyah yang telah ditentukan kemudian pada tes tulis siswa menulis huruf hijaiyah pada lembar jawaban yang telah disediakan. Tujuannya untuk mengetahui sejauh mana tingkat kemampuan pemahaman siswa tunarungu terhadap pembelajaran huruf hijaiyah dengan memberikan pembelajaran huruf hijaiyah pada saat fase baseline dan fase intervensi.

Sunanto (2005, hlm. 93) menyatakan bahwa analisis data merupakan tahap terakhir sebelum menarik kesimpulan. Pada penelitian dengan subyek tunggal data disajikan dengan menggunakan statistik deskriptif yang berbentuk grafik. Kemudian data dianalisis dengan perhitungan menggunakan analisis dalam kondisi dan analisis antar kondisi. Hal tersebut dilakukan dengan tujuan untuk memperoleh gambaran secara jelas atau mengetahui data sejauh mana siswa mengalami peningkatan dalam memahami huruf hijaiyah dengan menggunakan multimedia interaktif berbasis adobe flash dalam jangka waktu tertentu.

\section{HASIL PENELITIAN}

Penelitian ini dilakukan dalam dua fase yaitu fase pertama adalan baseline (A) dan fase kedua ialah intervensi (B). Pada fase baseline pengambilan data dilakukan sebanyak 5 sesi dengan mendapatkan presentase $60 \%, 66 \%$, 66\%, 70\%, dan 60\%. Setelah data pada fase baseline stabil maka dilakukan pada tahap fase selanjutnya yaitu fase intervensi. Pada fase intervensi pengambilan data dilakukan sebanyak 5 sesi dengan menggunakan multimedia interaktif. Adapun presentase pada fase intervensi yaitu 77\%, 73\%, 80\%, 83\% dan $\quad 83 \%$. Untuk mengetahui kemampuan memahami huruf hijaiyah dari data baseline (A) dan data intervensi (B) maka disajikan dalam bentuk grafik sebagai berikut:

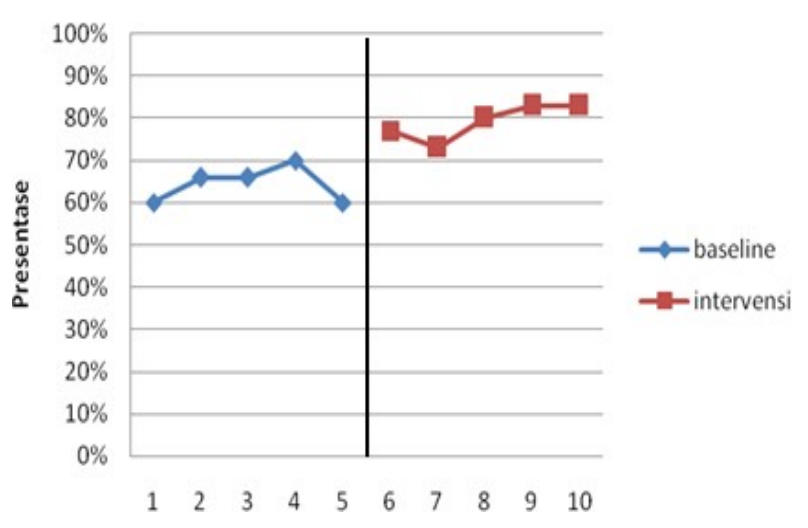


RANGKUMAN HASIL ANALISIS DATA

Hasil analisis dalam kondisi

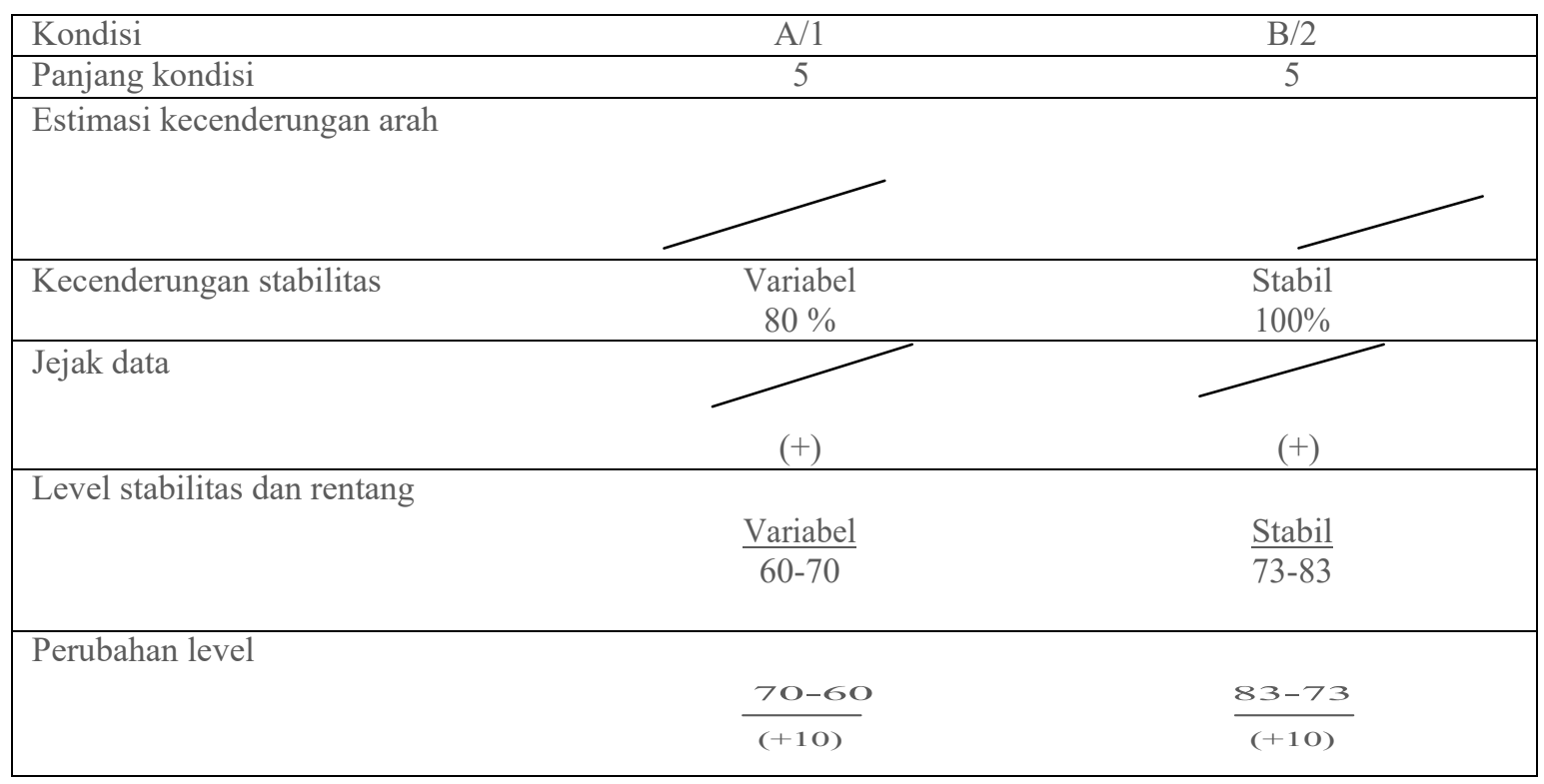

Tabel analisis antar kondisi

\begin{tabular}{|lc|}
\hline Kondisi & \multicolumn{2}{|c|}{$\mathrm{B}_{1} / \mathrm{A}_{1}$} \\
\hline Perbandingan kondisi & $2: 1$ \\
\hline Panjang kondisi & 1 \\
\hline Estimasi kecenderungan arah & $(+)$ \\
\hline Perubahan kecenderungan & \\
stabilitas & Variabel ke stabil \\
\hline Perubahan level & $(+17)$ \\
& \\
\hline Persentase overlap & $0 \%$ \\
\hline
\end{tabular}




\section{PEMBAHASAN}

Salah satu siswa tunarungu kelas IX SMP adalah subjek dalam penelitian ini dengan inisial BG. BG dalam memahami huruf hijaiyah masih minim, BG mampu membaca huruf hijaiyah hanya beberapa (alif, ba', ta', tsa, jim, ha, kho) membaca huruf hijaiyah jim, ha, kho pun BG masih sering terbalik dikarenakan huruf hijaiyah tersebut memiliki bentuk sama yang membedakan ialah hanya letak titiknya. Dalam penelitian ini digunakan multimedia interaktif berbasis adobe flash. Multimedia interaktif berbasis adobe flash ini terdapat beberapa komponen (teks, gambar dan pemrograman) yang mendukung dalam pembelajaran huruf hijaiyah terhadap siswa tunarungu ringan.

Penelitian ini dilakukan setelah anak mengikuti pelajaran atau pada jam istirahat selama 10 sesi pada 2 kondisi yaitu, 5 sesi pada kondisi baseline (A) dan 5 sesi pada kondisi intervensi. Pada fase baseline (A) menunjukan kondisi awal kemampuan dalam memahami pembelajaran huruf hijaiyah dengan presentase $60 \%, 66 \%, 66 \%, 70 \%$, dan $60 \%$. Pada fase baseline (A) persentase nilai terendah adalah $60 \%$ dan persentase nilai tertinggi $70 \%$.

Pada fase intervensi

presentase yang didapat antara lain $77 \%, 73 \%, 80 \%, 83 \%$ dan $83 \%$. Kemampuan memahami BG pada fase intervensi (B) memiliki presentase terendah $73 \%$ dan tertinggi $83 \%$. Pada sesi pertama BG mampu menggunakan multimedia http://doi.org/10.31537/speed.v3i2.282 interaktif dengan baik sehingga BG mendapatkan presentase lebih tinggi yaitu $77 \%$, jika dibandingkan dengan presentase sesi terakhir pada fase baseline.

Hambatan BG dalam menjawab soal ialah mengisyaratkan huruf hijaiyah "fa", karena isyarat fa yang hampir sama dengan isyarat huruf hijaiyah qof, wau dan ha' (perbedaannya ialah penggunaan dan letak jari). Kondisi BG dalam mengikuti pembelajaran baik, juga antusiasnya semakin tinggi dalam memahami huruf hijaiyah. Hal

ini dibuktikan dari hasil skor yang didapat BG ialah 25 dari skor maksimal 30. Artinya BG mampu mengikuti pembelajaran tentang huruf hijaiyah dengan menggunakan multimedia interaktif serta semangat dan cepat dalam menjawab tes yang diberikan.

Analisis yang dilakukan dalam penelitian ini yaitu analisis dalam kondisi dan analisis antar kondisi. Hasil pengolahan dan analisis data secara menyeluruh menunjukan bahwa penggunaan multimedia interaktif berbasis adobe flash dalam pembelajaran huruf hijaiyah berpengaruh terhadap pemahaman siswa tunarungu ringan. Hal tersebut dapat dilihat dari peningkatan presentase kemampuan memahami huruf hijaiyah sebelum dan setelah mendapatkan intervensi berupa penggunaan multimedia interaktif. Mean level yang diperoleh subjek pada fase intervensi (B) 79 yaitu lebih tinggi jika dibandingkan dengan fase baseline 64,4. Serta selisih level perubahan dari fase 
baseline (A) sampai awal fase intervensi (B) meningkat (+17). Selisih level perubahan kemampuan BG pada fase intervensi (B) mengalami peningkatan dari fase baseline (A) dengan menggunakan multimedia interaktif. Hal ini dipengaruhi oleh partisipasi siswa yang baik ketika melakukan pembelajaran huruf hijaiyah dengan menggunakan multimedia interaktif berbasis adobe flash.

Dari pembahasan di atas maka dapat dibuktikan bahwa multimedia interaktif dapat berpengaruh terhadap pemahaman huruf hijaiyah pada siswa tunarungu ringan kelas IX di SLB B dan AUTIS TPA Jember.

\section{PENUTUP}

\section{Simpulan}

Penelitian yang telah dilakukan di SLB-B dan Autis TPA Jember Tahun Ajaran 2018/2019 diperoleh hasil bahwa ada pengaruh multimedia interaktif terhadap pembelajaran huruf hijaiyah pada siswa tunarungu ringan kelas IX.

Penggunaan multimedia interaktif berpengaruh dalam pembelajaran huruf hijaiyah terhadap BG. Hal ini dibuktikan dengan hasil penelitian yang terjadi perubahan terhadap kemampuan memahami huruf hijaiyah pada siswa tunarungu ringan dengan menggunakan multimedia interaktif. BG yang awalnya hanya mampu mengetahui 7 huruf hijaiyah, kemudian setelah pemberian treatment BG mampu mengetahui 29 huruf hijaiyah. Pada fase baseline (A) persentase terendah $60 \%$ dan persentase tertinggi $70 \%$ dengan mean level 64,4. Sedangkan pada fase intervensi (B) persentase terendah $73 \%$ dan persentase tertinggi $83 \%$ dengan mean level 79. Selisih perubahan level dari fase baseline (A) sampai awal fase intervensi (B) meningkat $(+17)$. Selisih perubahan level kemampuan $B G$ pada fase intervensi (B) meningkat dari fase baseline (A) dengan menggunakan multimedia interaktif. Presentase overlap $0 \%$ artinya pengaruh multimedia interaktif terhadap pembelajaran huruf hijaiyah sangat baik.

\section{Saran}

Berdasarkan penelitian yang telah dilakukan, maka saran ada beberapa saran dari penelitian ini, yaitu sebagai berikut: (a) Bagi peneliti selanjutnya, dapat mengkaji dan mengadakan penelitian lebih lanjut tentang penggunaan multimedia interaktif dalam meningkatkan kemampuan memahami pembelajaran huruf hijaiyah pada anak berkebutuhan khusus. (b) Bagi pihak guru dan sekolah, dalam pembelajaran huruf hijaiyah penggunaan multimedia interaktif dapat membantu siswa dalam mencapai tujuan pembelajaran memahami huruf hijaiyah. Berdasarkan hal positif dari penelitian ini diharapkan multimedia interaktif dapat menjadi salah satu alternatif yang dapat diterapkan oleh guru dalam mengembangkan dan meningkatkan kemampuan memahami pembelajaran huruf hijaiyah. 


\section{DAFTAR PUSTAKA}

Abdurohim, Acep Iim. 2007. Pedoman Ilmu Tajwid Lengkap. Bandung: CV Diponegoro.

Sunanto, juang. 2005. Pengantar Penelitian dengan Subjek Tunggal. Bandung: UPI

Hernawati, Tati. 2007. Pengembangan Kemampuan Berbahasa dan Berbicara Anak Tunarungu. Jurnal Asesmen dan Intervensi Anak Berkebutuhan Khusus, 7 (1): 101-110.
Apriliani, Lia. 2013. Penggunaan Media Adobe Flash dalam Meningkatkan Kemampuan Mengingat Huruf Hijaiyah pada Anak Tunarungu Kelas 4 SDLB di SLB Negeri Cicendo Kota Bandung. Skripsi diterbitkan. Bandung: FIP UPI. (http://repository.upi.edu/id/epr int/143) diakses 19 April 2018.

Mais, Asrorul. 2016. Media Pembelajaran Siswa Berkebutuhan Khusus. Jember: CV Pustaka Abadi. 